\title{
Creating service excellence through Human Resource Management practices
}

\author{
Victoria Browning \\ Graduate School of Business, University of Cape Town, Private Bag, Rondebosch. 7001 Republic of South Africa \\ vickybro@gsb2.uct.ac.za
}

Received September 1998

\begin{abstract}
Service excellence has become a critical source of competitive advantage for organisations. This article focuses on the interaction between the frontline employee and the customer and the role of Human Resource Management (HRM) in sustaining service-orientated behaviour. The nature of the relationship between HRM and service behaviour is also explored, focusing on three possible intervening variables - commitment to customer service. job competence and organisational identification. The implications of this relationship for business managers are highlighted and it is suggested that to achieve service excellence, managers need to focus as much on their internal relationships with employees as they do on their external relationships with customers, as their contribution to organisational performance is inter-linked. Directions for future research in redefining HRM practices and determining the nature of the link between HRM and service-orientated behaviour are discussed.
\end{abstract}

\section{Introduction}

The service industry now accounts for $60 \%$ of the world's economic activity (Irons, 1994). This move towards a service economy has meant that service has increasingly become as important as the products on offer and, as such, of the jobs within an organisation (Morrison, 1996). As a key discriminator between products and services offered by organisations competing for the same market share, service excellence has become a critical source of competitive advantage (Horwitz $\&$ Neville, 1996). Customers who are dissatisfied with the quality of service can, and do move their custom elsewhere. As South Africa enters the global economy, so it becomes important that the issues of service are addressed as a matter of priority, if as a country, it is to be able to compete in the international arena.

For customers, an experience of excellent service is the result of their needs and expectations being exceeded. The quality of the service interaction between service provider and customer is an important part of a customer's experience of service. It is this interaction which will be the focus of this article, and research will be presented which links the human resource management practices within organisations to the service behaviour of frontline employees. Implications of these findings for managers and for future research will also be discussed.

\section{Service-orientated behaviour}

Service is a 'personal and psychological experience' (Schneider \& Bowen, 1993: 39) between the frontline employee and the customer. The nature of this service interaction is that it is a consumptive act. The service is produced and consumed simultaneously and therefore difficult to preserve for both current and future evaluation. The content of the interaction can also vary considerably from industry to industry, and from interaction to interaction. The intangible and variable nature of the service interaction between the frontline employee and the customer has made it difficult to specify what effective service behaviour is (Morrison, 1996). This is further complicated by the impact of customer expectations on what is good service behaviour. which could be influenced by the product and the nature of the service being provided.

Zerbe, Dobni \& Harel (1993: 7) conceptualised service behaviour as 'the nature and content of the interpersonal interaction between service providers and customers'. In a study done in 1992, Zerbe found that the degree of positive behaviour employees showed towards passengers (happy, pleased) was strongly related to airline passenger satisfaction with customer service provided both by the airline and the individual employee (Zerbe et al., 1993: 8). While Zerbe et al. (1993) define service behaviour in terms of positive behaviour towards customers, Morrison (1996) identifies activities and behaviours. The employees of organisations who excel in customer service, engage in specific and exceptional levels of behaviour which she links to organisational citizenship behaviour (OCB). OCB has five distinct dimensions, which Morrison believes contribute to service excellence. The first dimension is going that extra mile; the second is helping and supporting others (altruism) and the third, the willingness to support one's organisation (civic virtue). The fourth dimension is the willingness to tolerate difficult circumstances without complaining (sportsmanship) and the fifth dimension is respect and consideration for fellow employees.

Much of what Morrison describes as service-orientated behaviour is captured in Peccei \& Rosenthal's (1997: 69) definition of the behavioural manifestations of commitment to customer service (CCS) as 'the relative prosperity of an individual to engage in continuous improvement and to exert effort on the job for the benefit of customers'. Serviceorientated behaviour requires a focus on customers' needs and taking action, often beyond the call of duty, to meet these needs. Spencer \& Spencer (1993) found that employees who are not committed to providing good customer service focus primarily on their needs or those of the organisation, at the expense of the client. They are unclear about the real needs of the client, and tend to blame customers and make global negative comments about customers. They make very little effort to assist customers and resent troublesome customers. Employees committed to service excellence have a clear understanding of customer queries and complaints and take 
personal responsibility for correcting customer service problems without becoming defensive. Not only do they exert extra effort. to satisfy the customer's needs, but they ask others to assist them when necessary.

\section{Link between Human Resource Management (HRM) and service-orientated behaviour}

Research by Zerbe, Dobni \& Harel (1993); Bowen \& Lawler (1992); Schneider \& Bowen (1985, 1993); Huselid (1994); and studies on Delta Airlines (Ulrich, 1992) and Southwest Airlines (Hallowell, 1996) have highlighted the importance of the relationship between human resources management, service-orientated behaviour and ultimately organisational effectiveness. Ulrich \& Lake (1990) define organisational capability as

'(a) business's ability to establish internal structures and processes that influence its members to create organisation-specific competencies and thus enable the business to adapt to changing customer and strategic needs' (Hallowell, 1996: 522).

Employees who perceive the internal structures and practices positively, display positive service behaviour towards customers (Schneider \& Bowen, 1985, 1993; Zerbe et al., 1993). How employees are treated within their organisation influences the way they behave towards the customer thereby impacting on the customer's experience of service. Much of what happens inside an organisation cannot be hidden from the customer (Schneider \& Bowen, 1993). Customers have a strong sense of what is going on in an organisation (Schneider, White \& Paul, 1997).

Respect for each individual employee and fair management of performance, combined with a genuine caring for people, seems to have been the magic and effective combination of ingredients in the case of Southwest and Delta Airlines (Hallowell, 1996; Ulrich, 1992). It required a paradigm shift within the minds of management to view employees with the potential to add value rather than as a cost to the organisation. The focus was on the human side of people management and to see employees as an asset. This combined with the effective management of that asset, played a key role in creating the service excellence and a competitive advantage of these organisations.

\section{Human Resource Management (HRM)}

In teasing out the differences between personnel management and human resources management, an attempt has been made to establish exactly what is meant by human resource management. An examination of the fundamental elements underlying the concept of human resource management highlights some general differences. HRM focusses both on management and employees alike, while personnel management appears to be performed by management on and for employees. HRM is seen as a key role of management and HRM policies and activities as an integral part of the business strategy. Linked to this, is the HRM emphasis on its role in organisational change and the management of organisational culture, whereas personnel management does not seem to be seen in this light

A distinction has been made between 'hard' and 'soft' versions of human resource management with the former empha- sising employees as an asset to be used dispassionately and in a rational manner, the latter emphasises building and maintaining relationships. It is the employees who make the difference to the success of the organisation and human resource management forms a strategic part of the organisation both underpinning and moving the organisation towards excellence and success. Human resource management also sug. gests an integrated and systematic approach to managing human resources through policies and practices such as recruitment, selection, appraisal, training and development and performance management. It is a

'distinctive approach to employment management which seeks to achieve competitive advantage through strategic deployment of a highly committed and capable workforce using an integrated array of cultural, structural and personnel techniques' (Storey, 1995: 5).

Schuler (1992)5-P divides strategic human resource management into five key areas which influence each other. $\mathrm{Hu}$ man resource philosophy which defines the values and beliefs behind the treatment of people. This, in turn, influences the human resource policies which are guidelines on how to deal with people-related issues. These are articulated in human resource programmes or strategies which, in turn, define the human resource practices. These encapsulate the roles and activities which leadership and management should take on to support the strategies. Finally, what Schuler terms as human resource processes is how the human resource management activities are carried out. For example, high involvement/high participation or low involvement/low participation.

\section{Impact of Human Resource Management}

The impact of human resource management on job performance has been researched within service organisations by Schneider \& Bowen (1985, 1993), Schneider, White \& Paul (1997), Hallowell (1996) and Zerbe et al. (1993). In Schneider \& Bowen's research in a full service commercial bank, customers were asked to consider five dimensions of service which included courtesy/competence; utility/security; adequate staffing; employee morale; and branch administration (how well the branch seemed to be run and administered). Customers also indicated their attitude to the overall quality of service they received at the branch. Employees were asked to rate the human resource practices which fell into five dimensions - work facilitation; supervision; organisational career facilitation, organisational status and new employee socialisation. The objective was to establish if employee perceptions of human resource practices would be positively related to the customers' perception of service. A positive perception by employees of work facilitation (factors in the organisation and in their jobs which assist or restrict job performance) was related to customers' favourable perception of all the dimensions of service except utility and security of the bank's service (convenience and range of service provided). Employees' perception of all the human resource dimensions impacted on the customers' perception of employee morale (employee attitudes and turnover) and branch administration. The employees' perception of socialisation did not, however. correlate with the customers' perception of branch administration and there was a particularly low correlation (below $.31 ; p>.05$ ) between customer perceptions of courtesy or 
competence and adequate stating, with employees perceptions of all the human resource dimensions except work facilitation.

With the correlation's ranging from $.30(\mathrm{p}-05)$. between all the human resource dimensions and the overall perceived quality of customer service, it is evident that there is a link between human resource management practices and employee performance in terms of customer service.

Zerbe et al. (1993) focussed more specifically on service behaviour, and found a significant correlation between employees' display of positive behaviour towards customers and the six human resource management (HRM) practices measured - leadership, rewards, career opportunities, performance appraisal, work demands and training. A regression analysis on service behaviour highlighted leadership, career opportunities and work demands as being the most significantly associated with employees' positive perception of their service behaviour. The added value provided by Zerbe et al.'s (1993) research support the results provided for a mediation model of HRM practices influencing a service culture, which in turn, has an impact on service behaviour. The research contests the proposal that employee service behaviour is a consequence of a service culture. A service culture is a consequence of HRM practices. and in this way, it has an impact on service behaviour, This. with the significant correlation between HRM practices and service behaviour, strengthens the argument for the link between HRM practices and employee behaviour.

\section{Intervening variables}

The critical question to ask now is why HRM practices have this impact. Zerbe et al. (1993: 12) propose that satisfaction with humam resource activities results in overall job satisfaction which increases the level of job performance. In addition, an employee could provide a higher quality of service to balance the scales (equity theory) and also, that effective human resource management practices communicate management expectations of good customer service to employees. Commitment, competence and congruence have been highlighted by Beer, Spector, Lawrence, Mills \& Walton (1984) and Guest (1989) as amongst the human resource outcomes of HRM practices which would impact on employee performance and ultimately result in increased organisational effectiveness.

\section{a. Commitment 10 customer service}

A commitment to customer service (CCS) is an attitude and a behaviour to which limited attention has been paid. In their research Peccei \& Rosenthal (1997) discovered that on the whole, the normative and affective orientations to customer service tended to most significantly result in a commitment to customer service. Normative orientation reflects the employees' belief that it is their duty and the customers' right to receive good customer service. Affective orientation, on the other hand, reflects enjoyment and personal satisfaction with providing good service to customers.

\section{b. Compelence}

Job competence and understanding of customer service, both capacity variables, also had a significant impact on CCS. Too much routine in a job has a negative relationship with CCS
(Peccei \& Rosenthal, 1997). This result supports the move to empower frontline employees, both in terms of knowledge and skills, and to allow them the autonomy to carry out their job function. It is plausible in light of the results obtained by Peccei \& Rosenthal (1997) that competence could impact positively on service behaviour and as such on customer service.

\section{c. Organisational identification}

Identification with organisational goals can be seen as another intervening variable through which HRM practices could have an impact on employee behaviour. Organisational identification is characterised by a feeling of oneness and connectedness with the values and products and issues surrounding the organisation (Elsbach \& Bhattacharya, 1997). In line with the social identity theory, one's social identity, which forms part of one's self concept. is based on links with the organisation. Employees will identify strongly with their organisation if they have an image of their organisation as prestigious, are satisfied with being part of their organisation and have long service (Elsbach \& Bhattacharya, 1997). Schneider \& Bowen's (1985, 1993) results indicated that the status and image employees believe the organisation has in the eyes of outsiders increases employee morale $(.54, \mathrm{p}<.05)$ and the overall quality of customer service $(.56, p<.05)$. Organisational identification is therefore important because of the impact it has on service quality and. more specifically, on the individual level of job performance. Morrison (1996) proposes that to the extent that HRM practices establish social exchange.' identification with the objectives of organisation and empowerment, so they will impact on the level of organisational citizenship behaviour and on service-orientated behaviour.

\section{Implications for managers}

An understanding of the relationships between the various variables impacting on service behaviour and the management thereof, would be an important consideration for managers within service organisations.

Figure 1 illustrates the proposed relationship between human resource management (HRM) and service behaviour which results in customer satisfaction. These relationships currently under empirical investigation (Browning. 1997) have implications for the management of frontline employees. Frontline employees are those employees who have direct contact with the public either face to face or telephonically. Organisations invest time and money in the training of these employees in customer service skills. To a large extent however there has not been a sustainable impact on performance of the employees. What is evident in the relationships illustrated in Figure 1, is that service behaviour is influenced by more than just knowledge and skills development. Attitudes such as customer orientation and identification and commitment to organisational goals have an influence. In order to enhance the service behaviour of their employees, managers need to focus on the HRM practices within their organisation which will, it is proposed, have a positive impact on these intervening variables. and therefore service behaviour. 


\section{Impact}

- Increases compctencc

- Increases commitment to

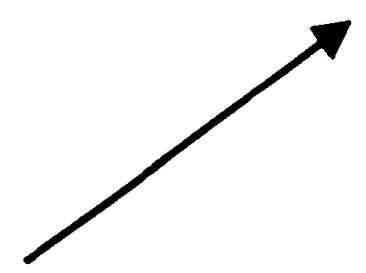

customer service

- Increases organisational identification

\section{HRM Practices}

\section{- Staffing}

- Retention

- Development

- Adjustment

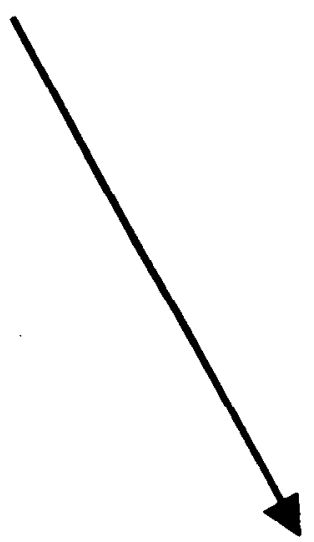

\section{Result}

Sustained

Service Orientated

Behaviour

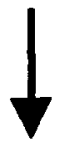

Customer Satisfaction

Figure 1 The relationship between HRM practices and service behaviour

Casio (1995) identifies four key practices which make up the human resource management role of managers:

- Staffing which includes job profiling, human resource planning, recruitment and selection;

- Retention which includes rewards, health and safety, and working relationships;

- Development with activities such as training and development and performance management; and

- Adjustment which comprises activities such as discipline, and counselling which are intended to maintain commitment to human resource policies and organisational goals.

Downsizing or strategic readjustment of the business will have an impact on the staffing activities, the new job requirements and the type of individuals needed to drive the strategic initiative. The type of staff employed will influence the training and development necessary and the compensation systems put into place. Clearly, changes in one area will reverberate through other areas. Understanding and marrying the relationship between the HRM practices and the consequent impact on the employee requires a systems approach, which emphasises the interrelatedness of different areas and activities on each other. The HRM practices are interlinked and all have an impact on the employee resulting in sustainable service-orientated behaviour. Several important implications for managers therefore need to be considered in relation to their human resource management role.

\section{Staffing}

Strategic staffing, human resource planning and thorough comprehensive recruitment and selection can ensure that candidates with the competence and commitment to add value are brought into the organisation. South West Airlines (Hallowell, 1996) places strong emphasis on the process of recruitment and selection, involving employees and customers and focussing on the values and attributes of candidates rather than knowledge, skills or qualifications. Henkoff (1994: 58) quotes a president of a travel company who states 'It doesn't matter what your résumé says. The main prerequisite is that you are nice'. It is important that the competencies which make for effective service workers within an organisation are identified and guide the selection of potential employees. Spencer \& Spencer (1993) based on work by David McClelland \& Richard Boyatzis, identify three levels of job competencies. ${ }^{2}$

The third level of competencies - motives, values and traits - are deep and central to the personality. It is this level of competencies which drive and explain the difference between average and superior job performers. The key is to select for the third level of competencies. As Henkoff (1994: 57) puts it. you identify a person's passions and match him to the right job. Attitudes and perceptions of oneself and one's role, the second level of competencies, are an outcome of a person's values, motives and traits. Skills and knowledge, the first 


\begin{tabular}{|l|c|}
\hline Level 1 & $\begin{array}{c}\text { Skills } \\
\text { Knowledge }\end{array}$ \\
Level 2 & Self Concept \\
Attitudes & \\
Level 3 & Traits \\
Motives \\
Values
\end{tabular}

Figure 2 Three levels of competencies (Adapted from Spencer \& Spencer, 1993: 11)

level of competencies, are more tangible and visible. Unlike the core personality, they are easier to develop.

\section{Retention}

Positive and constructive relationships between co-workers and between management and employees have an impact on employees' commitment to an organisation and the motivation to go that extra mile. Schneider \& Bowen (1985, 1993), Zerbe et al. (1993) and Gwangwa's research (1997) support the relationship between leadership/supervision and employee work behaviour and customer service. Managers need to make an honest and serious evaluation of their leadership style and ability to engage in behaviours which would be perceived positively by employees - providing feedback, establishing and providing rewards, sharing information, promoting team work, and treating employees with respect and empathy.

Work facilitation which involves providing employees with information, materials, equipment and ongoing guidance has a significant impact on employee behaviour and their ability to perform their job effectively (Schneider \& Bowen, 1985, 1993; Schneider, White \& Paul, 1997). Gwangwa (1997) found a significant relationship between infrastructure and support and employees' positive perceptions of customers' perceptions of service. The implications are that managers need to focus on employees' access to resources, the design of their jobs and work processes to facilitate task performance. Managers need to provide both moral support and the necessary infrastructure so that employees can basically get on with the job.

\section{Development}

Relevant training and development and effective performance management will increase the competence of employees and their commitment to customer service and organisational goals. Peccei \& Rosenthal (1997) suggest that job and customer care training and employee development in general are important in addressing the capacity of employees to perform their jobs effectively and their commitment to providing quality customer service. Both Schneider \& Bowen's (1985, 1993) research and that of Zerbe et al. (1993) supports the importance of developing organisational systems and practices which support career development. Information and counselling needs to be easily accessible to employees, and performance appraisals need to provide honest and constructive feedback to employees

\section{Conclusions and implications for future research}

Clearly the link between HRM practices and service quality is a complex one. The key role of service in creating competitive advantage underlines the importance of providing some additional empirical evidence of what, up to now, has been primarily conjecture, and plausible conjecture at that, that HRM activities within an organisation have a significant impact on service behaviour. Not only does the relationship between HRM practices and service behaviour need further investigation, but so does the role of the intervening variables such as employee attitude and behaviour, particularly at the individual level. The limited focus on service behaviour per say, indicates a need for further research to describe service behaviour more concisely and to assess the impact of HRM activities on this individual level of behaviour.

Browning (1997) has proposed several directions for future research into the link between HRM activities and service behaviour. Firstly, what do we really mean by human resource management, what is included and what is excluded from the definition? What do we mean by such activities as recruitment, selection, induction, compensation, performance management and appraisal? Churchill (1979) criticised marketing for widely varying definitions of the same construct and maintained that measures were inadequate, and their relevancy, validity and reliability were questionable. The definitions and measurement of human resource management activities seems to be in danger of being vulnerable to the same criticisms. With the reassessment of both the role of and, as such, the definition of human resource management in organisations, previous constructs, definitions and measures need to be re-examined. Our understanding of HRM is based on assumptions of human nature which are essentially Western, Eastern and European in origin. The emerging definition and underlying assumptions of African management needs consideration when assessing HRM within the South African context. Christie (1996) identifies four approaches to management: pragmatic, rational, developmental and metaphysical. The latter, being essentially the domain of Africa, focusses on feelings, values, spirituality and concern for the individual as part of a group. Management within the context of Africa needs to be balanced, using the advantages of different approaches to management from America, Europe, the East and Africa. Rather than use the definitions and terms used in research up to this point by Schneider \& Bowen (1985, 1993), ${ }^{2}$ Zerbe et al. (1993) and Schneider, White \& Paul (1997), research could focus on redefining terms and constructs by following the procedure suggested by Churchill (1979). Research could also determine the relative impact of various human resource practices on service behaviour. Do 
some actirities have a stronger impact on service behaviour than others?

Secondls. further exploration is needed to determine which intervening variables provide a link between HRM practices and service behaviour. Possible variables to investigate are overall job satisfaction, employee commitment to the customer service focus of an organisation, the perceived competence by employees to provide quality customer service and the identification of employees with the organisation.

It would also be important to not only determine the intervening variables but also the nature of the link they provide between HRM practices and service behaviour. Zerbe et al. (1993) in their research tested the mediating or moderating role of service culture on human resource management and service behaviour. A similar emphasis on intervening variables could determine whether:

- Employees who perceive HRM practices positively and whose service behaviour is perceived positively by customers. will have a higher level of overall job satisfaction, commitment to customer service, perceived capacity to perform and organisational identification. This would support the moderating effect of intervening variables.

$\mathrm{Or}$

- A positive perception of HRM practices increases the level of job satisfaction, commitment to customer service, perceived capacity to perform and organisational identification. This will be positively related to the customer's perception of the service behaviour. This would support the mediating effect of the intervening variables.

A cautionary note here, emphasised by James \& Brett (1984), is that the distinction between a mediator and a moderator is not so clear cut. A well specified causal model with empirically demonstrated fit between model and data needs to exist and specification errors need to be addressed."

Of final consideration for research would be establishing what is exactly meant by service-orientated behaviour. In establishing a profile of service-orientated behaviour, focus groups of customers could be asked: what does an above average frontline employee do differently from a more average frontline employee, when providing service to you as a customer? The focus would be on behaviour, as it is the behavioural manifestation of the employees' attitudes which make a difference to day-to-day service. (Peccei \& Rosenthal, 1997). The application of a contingency approach to what is defined as superior service behaviour would also be appropriate. How would the nature of service and product being provided impact on the service behaviour expected from frontline employees? Would customers expect different behaviours from a petrol pump attendant to tellers in a bank or sales assistants in a departmental store? Would expected service behaviour differ between different types of outlets such as convenience stores. supermarkets and boutiques?

Research to establish the link between HRM activities and service behaviour has implications not only for academic research but for managers. Firstly, it emphasises the need for management to focus on their HRM practices to play a strategic role in establishing a reputation of service excellence for their organisation. Managers need to recognise that the responsibility for the effective utilisation and management of hunan resource processes and systems is their responsibility and not that of the human resource department. Secondly, that it is as important to manage both external and internal relationships. This means managing the level of service provided to customers and at the same time managing relationships with employees. Both the external and internal relationships are interlinked. It is this fundamental understanding that human resource management plays a critical role in creating and sustaining service excellence which will give an organisation the competitive edge.

\section{Notes}

1. Morrison distinguishes between two forms of exchange relationships. Economic exchange which is contractual in nature, and social exchange which rests on trust and requires limited concern for immediate compensation but rather long-term benefits.

2. Spencer \& Spencer (1993: 9) define a competency as "an underlying characteristic of an individual that is causally related to criterion - referenced effective and/or superior performance, in a job or situation

3. As examples of specification errors. Jones \& Brett (1984) specify unmeasured variable problems and mix-specified causal directions.

\section{References}

Beer. M.. Spector. B.. Lawrence P.R., Mills. D. \& Walton, R.E. 1984. Managing human assets. 4th ed. New York: Dryden Press.

Blythe. P. \& Turnbull. P. 1992. HRM: debates. dilemmas and contradictions. In Blythe. P. \& Turnbull. P. ed. Reassessing Human Resource Management. London: Sage Publications.

Bowen. D.E. \& Lawler. III E.E. 1992. The empowerment of service workers: what. why. how and when. Sloan Management Review. Spring: 31-39.

Browning, V. 1997. An investigation into the relationship between Human Resource Management activities and service behaviour with consideration of customer expectations of service behaviour in the retail sector in South Africa. PhD proposal submitted to the Faculty of Commerce. University of Cape Town.

Casio, W.F. 1995. Managing human resources. 4th ed. USA: McGraw-Hill, Inc.

Christie, P. 1996. Stories from an African manager. Randburg: Knowledge Resources.

Churchill, G.A. 1987. Marketing research. Methodological foundations. 4th ed. New York: Dryden Press.

Elsbach, K.D. \& Bhattacharya. C.B. 1997. Organisational disidentification: a study of social identity and the national rifle association. Paper presented at Innovations in Social Marketing Conference, May

Elsbach. K.D. \& Bhattacharya, C.B. 1997. The individual and the organisation: understanding the roles of identification and disidentification in social marketing. Paper presented at Marketing Public Conference, May.

Gwangwa, L. 1997. An investigation of links between employee perceptions of human resource management practices and customer service. Unpublished research report submitted in partial fultilment for Masters in Business Administration. Graduate School of Business, University of Cape Town

Guest. D.E. 1989. Personnel and HRM: can you tell the difference"? Personnel Management, January: 48-51.

Hallowell, R. 1996. Southwest Airlines: a case study linking employee needs, satistaction, and organisational capabilities to competitive advantage. Human Resource Management, 35(4): 513534

Henkoff, R. 1994. Finding, training and keeping the best service workers, Fortune. 3: 52-58. 
Horwitz. F. \& Neville. M.A. 1996. ()tganisation design for service excellence: a review of the literature. Homem Resource Management. 4: $471-492$

Huselid. M.A. 1994. Documenting human resources effect on company performance. Iluman Resource Magazine. January: 79-85.

Irons. K. 1994. Managing service companies: stralcyies for success Wokingham: Addison-Wesle!

James. L.R. \& Brett. J.M. 1984. Mediators. moderators and tests for mediation. Journal of Applied Psychology, 69(2): 307-321.

Kerlinger. F.N. 1986. Foundations of behavioural research. New York: CBS College Publishing.

Kinnear. T.C.\& Taylor, I.R. 1991. Marketing research. An applied approach. 4th ed. USA: McGraw-Hill.

Leedy. P.D. 1993. Practical research planning and design. 5th ed. New York/Ontario: Macmillan Publishing Company.

Marx. S. \& Van der Walt, A. 1989. Marketing management. South Africa: Juta \& Co Ltd.

McCarthy, E.I. \& Perreault, W.D. 1993. Basic marketing. A glo- . bal-managerial approach. USA: Irwin.

Morrison, E.W. 1996. Organisational citizenship behaviour as a critical link between human resources management practices and service quality, Human Resource Management, 35(4): 493-512.

Noon, M. 1992. A map, model or theory. In Blythe, P. \& Turnbull, P. ed. Reassessing human resource management. London: Sage Publications

Parasuraman, A., Berry, L.L. \& Zeithaml, V.A 1991. Understanding customer expectations of service. Sloan Management Review, 39 48.

Parasuraman. A., Zeithaml., V. \& Berry, L. 1985. A conceptual model of service quatity and its implications for future research, Journal of Marketing, 49(985): 41-50.

Peccei. R. \& Rosenthal, P. 1997 . The antecedents of employee commitment to customer service: evidence from a U.K. service context. The International Journal of Human Resource Management.
$8(1) 66-86$

Pitt. L.F. Foreman. S.K \& Bromfield. 1). 1995 Organisatuonal com mitment and sers ice delivers: evidence from in industrial selling in the l!.K. The International Journal of Human Resomere Mathagement. 6(1): 369-389.

Schneider. B. \& Bowen, D. E. 1985. Employec and customer perceptions of service in banks: replication and extension. . Jommal of 1 ) plied Psychologn: 70(3): 423-433

Schneider. B. \& Bowen, D.E. 1993. The service organisation: human resources management is critical. Organisational Dinamics. Spring: 39-52.

Schneider, B., Parkington, J.J.. \& Buxton. V.M. 1980. Einployee and customer perceptions of service in banks. Administrative . Scienc' Quarterly. 25: 252-267.

Schneider. B., White. S.S. \& Paul, M.C. 1997. Linking service climate and customer perceptions of service quality: test of a causal model. In Press: Journal of Applied Psy chology.

Schuler. R.S. 1992. Strategic human resources management: linking the people with the strategic needs of the business, Organisational Dynamics, Summer.

Spencer. L.M. \& Spencer, S.M. 1993. Competence at work. models for superior performance. USA: John Wiley \& Sons. Inc.

Storey. J. 1995. Human resource management: a critical text London: Routledge

Tull, D.S. \& Hawkins, Del I. 1984. Marketing research measurement and method. A text with cases. 3rd ed. USA: Macmillan Publishing Company.

Ulrich. D. 1992. Strategic and human resource planning: linking customers and employees, Human Resource Planning, 15(2): 47-61

Zerbe. W.J, Dobni. D. \& Harel. G.H. 1993. Human resource management practices, service culture and service behaviour. Unpublished manuscript, Faculty of Management. University of Calgar! pp. $1-20$. 